\title{
The Importance of Part-Time Work to UK University Students
}

\author{
Zatun Najahah Yusof \\ University of Strathclyde \\ Carl Evans \\ University of the West of England
}

\begin{abstract}
The purpose of this paper is to examine the skills requirements of UK graduate jobs and compare these to part-time jobs typically undertaken by UK university students, to identify similarities and/or differences between them.
\end{abstract}

A content analysis of 100 graduate jobs and 100 part-time jobs was used as the basis of comparison. The person skills criteria was initially noted for graduate jobs and then this used as a basis for comparison against the part-time jobs. Quantitative analysis was carried out to determine the relationship between the two sets of skills criteria.

Twenty-seven skills criteria were identified in the graduate jobs. It was found that there was a close relationship between the criteria specified in graduate positions and part-time jobs. This highlights the importance of part-time working for university students to gain vital skills to support graduate job applications.

By demonstrating connections between the two types of jobs, and therefore meeting more criteria of the person specification, will hopefully contribute to convincing graduate employers of university students' work readiness. 
Keywords: Part-time working, graduate jobs, content analysis, work readiness

Paper Type: Research Paper 


\section{The Importance of Part-Time Work to UK University Students}

\section{Introduction - The Competitive UK Graduate Jobs Market}

Despite an increase in annual employment rates between 2008 and 2018 (DfE, 2019), UK graduates are facing increasing challenges to entering the graduate jobs market and securing an appropriate-level first position (Jones, 2017). A graduate job is one for which a degree is required of the postholder (Targetjobs, 2020), and it is therefore important for an individual, that a graduate-level position is secured post-graduation to justify the time and expense of university study. Yet, inequalities across the sector still exist, with some employers favouring graduates with degrees from prestigious UK universities (Jackson, 2013). Moreover, those individuals with family connections and established networks of contacts provide an advantage in securing higher-level graduate positions (MacMillan et al., 2015). In addition, the choice of degree subject, particularly those of a non-vocational nature, will further limit the breadth of appropriate and/or available graduate positions (Davies, 2020). There is however, evidence that some graduates have an unrealistic expectation prior to entering the jobs market, which restricts their jobs search process and therefore limit the posts they will consider applying for (Hedvicakova, 2018; Mckeown and Lindorff, 2011).

Nonetheless, the UK graduate jobs market remains competitive (Vendolska and Kacerova, 2016). The massification of higher education (Mok and Jiang, 2018; Tight, 2017) has resulted in more graduates pursuing the limited number of available vacancies. This intense competition may well lead to graduates accepting any available position in order to make those first steps into the workplace, since it is found that some graduates are mismatched to their jobs (Steed, 2018; Mavromas et al., 2013; Zakariya, 2017). Alternatively, graduates 
can delay their entry into the jobs market by seek to undertaking additional academic awards. Here, student numbers undertaking postgraduate study in the UK has increased by $4 \%$ to 585730 in the year to $2018 / 19$ (HESA, 2020). This can however, exacerbate the problem of overqualification (BBC, 2019; Hwang, 2017), a situation where graduates underutilise their education once in post, resulting in job dissatisfaction (Sam, 2019).

\section{An Uncertain Future for UK Graduates}

More recently the contemporary business environment renders graduate employment prospects for the immediate future uncertain. Arguments regarding the long-term impact on graduate careers of Brexit continue in the media (von Sternberg, 2019). Similarly, the impact of the Covid-19 virus on graduate careers is currently being assessed (Gordon, 2020), although current staffing levels especially in office environments in the UK have been significantly reduced (Sales and Tapfield, 2020). The Institute of Student Employers (2020) predicts a significant reduction in available entry-level jobs for Autumn 2020, resulting in a corresponding increase in competition for jobs for those graduating in summer 2020. In addition, World Bank (2020) is currently predicting a global recession, which will potentially further reduce graduate job availability.

\section{UK Graduates - work ready or not?}

In addition to the uncertainty created by Brexit and Covid-19, a constant challenge faced by graduates is that UK employers remain unconvinced about graduates' work-readiness credentials (Baska, 2019). While not all employers are adept at assessing the work readiness of graduates (Caballero and Walker, 2010), and employers and graduates may have differing perceptions as to what is meant by work readiness (Ayoubi et al., 2019; Mari et al., 2019), employers generally feel that graduates are not work ready (Chavan and Carter, 2018). It is 
the possession of what are known as 'employability skills' (see for example, Boden and Nedeva, 2010) which indicate the ability of individuals to do a job successfully that are sought by employers. Here, employers lay blame to the educational provision of universities (Little, 2005; Rhew et al., 2019) for focusing on technical skills, rather than developing desired softer or social skills, such as communication, inter-personal relationships and teamworking (Abdullah-Al-Mamun, 2012; Ellis et al., 2014; Garner et al., 2019). Consequently, employers feel that universities do not adequately prepare graduates for the workplace (Konig and Ribaric, 2019; Prikshat et al., 2019). This has led to a number of proposed solutions being offered, with Herbert et al. (2020) demanding more creative solutions from universities in developing appropriate student behaviours alongside academic studies and Jollands et al. (2012) seeking greater emphasis on project-based learning. However, Ritter et al. (2018) and Teng et al. (2019) seek a more radical curriculum re-design, focusing predominantly on the development of soft skills. With Kapareliotis et al. (2019) highlighting the usefulness of internships in raising graduates' awareness of the demands of employers, the importance of university students gaining some work experience prior to graduating now seems a priority (O' Brien et al., 2013). The Highfliers publication (2019) indicates that over a third of graduate recruiters warn that graduates who have had no previous work experience at all, are unlikely to be successful during the selection process. Additionally, research has indicated that work experience not only helps support job success postgraduation in securing an appropriate position (Jasiński and Bożykowski (2017) it also enhances individuals' job quality (Gonzalez-Roma et al., 2018). 
The Response of UK Universities

Consequently, universities in the UK have increased the content of work-integrated learning in degree programmes, particularly placement opportunities (Jackson, 2015). It has been found that a work placement, integrated into a learning programme can have a positive impact on job and career prospects (Brooks and Youngson, 2016) by allowing students to practice learned skills in a work setting, engage with practitioners get a better understanding of the respective occupational discipline (Jackson, 2015) and develop transferable skills (Paisley and Paisley, 2010). However, placements are not mandatory in all degrees, and their take-up when offered has not been universal among students (Crawford et al., 2016). In addition, employers have experienced challenges not only in supervising and establishing effective performance, but also in providing students with appropriate activities (Jackson et al., 2016). Moreover, the adverse impact of Covid-19 on placement activities is perceived by students to negatively impact on their ability to complete a work placement (NUS, 2020).

\section{University Students Part-Time Work Activity}

The value of part-time work undertaken by students prior to entering a placement has been noted to be beneficial in helping them orientate to the workplace (Neil et al., 2004). Yet, part-time work as an activity in itself, has been argued to help develop students' transferable skills, independent of work-integrated learning (Evans and Richardson, 2017). Increasing numbers of students work part-time while studying at university (BBC, 2015; NUS, 2019), primarily to earn income to support their lifestyle (Crockford et al., 2015; Richardson et al., 2009). If students could however, use their part-time work experience to reconcile acquired skills to those specified in graduate positions, they will be in a more 
competitive position at recruitment stage and be better placed to convince employers of their ability to contribute immediately once in the business arena. Yet students typically fail to articulate their part-time work experiences and the corresponding transferable skills acquired, during the graduate recruitment process (Aggett and Busby, 2011; Evans et al., 2015; Owen, 2001), possibly because they have difficulty in relating higher-levels skills developed at university, to the workplace (Cavanagh et al., 2015). The effective reconciliation of skills developed in part-time jobs to those of full-time graduate positions, would therefore, potentially pave the way for students to express them more fully in the graduate recruitment process. To what extent though, do the part-time jobs typically undertaken by university students demand the same or similar, personal skills as those of full-time graduate jobs?

\section{Focus of this paper}

The aim of this paper is to examine the specified skills requirements of graduate jobs and compare these to part-time jobs typically undertaken by UK undergraduate university students, to identify similarities and/or differences between the two.

It is hoped by identifying similarities between the required skills of full-time graduate jobs to part-time jobs typically undertaken by UK undergraduate students, that a more ready connection can be made to facilitate students' more effective graduate job applications. Moreover, by demonstrating connections between the two types of jobs, and therefore meeting more criteria of the person specification, will hopefully contribute to convincing graduate employers of students' work readiness.

While undergraduate students' part-time working has been scrutinised by researchers, this has largely focused on its impact on academic studies (see for example, Curtis and Shani, 
2002). This work therefore, offers originality by extending the views of Evans and Richardson (2017) by providing a more tangible connection between graduate jobs and the part-time jobs that students do alongside degree studies. In addition, this work should be welcomed at this time in supporting the work-related activities of university students, who may face uncertainty in the graduate jobs market courtesy of Covid-19, Brexit and a possible recession.

\section{Research Approach}

Graduate jobs listed on two jobs websites were analysed, one specialising in graduate jobs and one in all job types including those which specified graduate positions. Using two websites was deemed to be necessary to give a broad coverage of graduate positions and to avoid restricting the analysis to those employers with a structured graduate recruitment scheme only. Only UK jobs were analysed. The analysis took place over two days in February 2020, which was before any UK lockdown due to Covid-19, and could therefore be deemed to provide a more typical jobs offering than the current Covid-restricted environment. While over 1000 graduate jobs were listed across the two websites, only jobs that could be applied for by a general degree holders, such as business graduates, were noted, to avoid vocationally specific jobs such as medicine, engineering and science. A number of vacancies were repeated for different areas of the country and some jobs did not explicitly state person requirements and therefore these were ignored.. The first 100 good jobs observed were recorded to provide a useful sample. The jobs advertisements were analysed and the specified person skill criteria for each job noted, excluding academic study requirements such as ' $A$ ' levels or the degree. The jobs were not tracked-back by to the graduate employers website to see if any further information was available, only the skill criteria 
shown on the website advertisement were recorded. The number of citations (mentions) for each skill criteria was then noted down. As the words or phrases used in the job specifications were recorded, some of the criteria were deemed to be semantically close enough to bring together as one criteria, for example, versatile, flexible and adaptable, were deemed to be equivalent. The data was recorded on a spreadsheet to facilitate subsequent quantitative analysis.

A general jobs website offering part-time jobs vacancies was then examined, over two days in early March 2020. Again, the date is significant, since the research was conducted before the Covid-19 lockdown, which by closing shops, offices, restaurants etc. dramatically changed the nature of part-time jobs specified by employers. A search parameter of 25 miles of Bristol was used to limit the number of vacancies to review, although there were still over 3000 initial hits. A specific region of the UK was selected for part-time jobs, since it was felt that university students would seek such employment in relative proximity to their respective university campus. The Bristol area was selected because the area includes city, town, rural and coast settings, which was deemed to potentially offer a broad variety of part-time jobs to attract students. Only general part-time jobs were sought that might be appropriate for a university student studying business to apply for. Part-time jobs that specified specialist skills, such as computer programming or previous experience, were rejected. Similarly, those listed that were selling a franchise organisation or requiring questionnaire completion or completing surveys were ignored. Also, the working hours had to be 15 hours per week or less, since anything over this was felt to conflict with academic studies (Curtis, 2007), although there is research to suggest students do actually work in excess of this figure (McVicar and McKee, 2002). It was found that a number of jobs were duplicated on the website, as they were copied from different online sources, and there was 
also repetition for the same job, but in different locations. It was therefore decided to limit the number of part-time jobs to the first 100 good jobs encountered. The person specification skills stated for the 100 part-time jobs was firstly recorded and then examined against the person criteria skills specified for the full-time graduate positions, with the number of mentions recorded on a spreadsheet. Subsequent quantitative analysis was carried out to examine the relationship between the part-time jobs skills against the graduate skill criteria.

\section{Findings and Discussion}

Twenty-seven criteria were identified in the person specifications of the graduate jobs (see Table 1). These largely reconcile to previous works identifying transferable graduate skills (see for example, Saunders and Zuzel, 2010; Wellman, 2010). Similarly, McArthur et al. (2017) identified the importance of communication skills, and this was the most commonly occurring criteria here, by a significant margin of 41 citations. This demonstrates the critical importance of effective communication skills to graduates, with job specifications referring to a wide range of communication skill requirements, covering written, verbal and presentation, depending on the job. The next highest specified criteria were grouped in the 20-30 mentions bracket, and this included analytical skills, IT skills and organisational skills. In addition, the ability to connect with colleagues in a team working environment was deemed important, with 24 citations. Least specified was reliability/dependability, with only one citation in the jobs specifications. Similarly, hardworking/strong work ethic had a low number of mentions. Similarly, criteria centring on innovation and new ways of thinking received 23 mentions, suggesting that employers do not look to graduates to be workhorses, but people who can transform the business. Related and potentially reinforcing 
the need for graduates to be dynamic, was that willingness to learn was stated in 23 jobs, highlighting the importance of professional development of graduates to employers. This is an important criteria for graduates to note, that learning does not end upon graduation, but continues throughout ones career.

\section{[Table 1 to be placed here]}

It was expected that leadership would be highly specified, as employers look to graduates to take on leadership and management positions. Yet only nine out of the 100 jobs specified this criteria. This possibly indicates that employers will look to develop leadership skills of graduates once in post, selecting managers subsequently. This is possibly reinforced by the need for graduates to be ambitious, since this had 26 mentions. Flexibility was specified in 16 graduate jobs, and this supports the view of Vendolska and Kacerova (2016) who feel that flexibility and adaptability are important graduate criteria, again, supporting the requirement that graduates can embrace change.

When the specified person criteria for the part-time jobs were assessed against the graduate criteria (see Table 2), communication also scored highly with 47 mentions, but this time, team working scored higher with 52 citations. This could be the nature of part-time job work requiring greater emphasis on team working, for example, restaurant waiting staff need to work closely with bar and kitchen staff. The need for customer service skills were also highly sought by employers with 41 jobs specifying it, again reinforcing that front-line customer contact typical of jobs in hospitality and retail. While part-time posts are seeking staff who are positive, energetic and can work on their own initiative, employers do not want creative, innovative individuals, since this criteria failed to register any citations. Flexibility scored highly with 23 mentions, possibly because employers look to students to 
infill staffing gaps, cover shifts and offer adaptability regarding availability. It could also be that employers want staff to be multi-skilled and take on different roles within the work area.

\section{[Table 2 to be placed here]}

Further quantitative analysis was performed to assess any possible significant relationships between the stated graduate person attributes and part-time jobs, and to find out whether the job attributes differ in graduate and part-time employment. A regression analysis model was computed as illustrated in Figure 1 below. The correlation coefficient of $R^{2}=0.2616$ suggests a good relationship. This figure indicates that there is only $26 \%$ of variability in graduate attributes, as explained by the regression of graduate attributes on part-time attributes.

The model, $y=0.4341 x+13.484$, where part-time job attributes $(x)$ could contribute towards the attributes of future graduate jobs $(\mathrm{y})$, demonstrates a significant relationship between variables (part-time and graduate attributes) where the $p$-value of 0.00 is less than the alpha value of $0.05(\alpha)$. The result also indicates that there were no large differences between graduate and part-time attributes, and that working part-time while in higher education is an important enhancement of graduate attributes and employability. This is an especially important finding for university students, who can look to part-time work to improve their work-readiness credentials and enhance graduate applications as a result. Further details of this analysis can be found in Appendix 1.

\section{[Figure 1 to be placed here]}


The 27 skills criteria specified in the job advertisements were then sub-divided into three categories, with 12 attributes considered as skills, 7 for traits and 8 attributes allotted to behaviours. Traits are related to an individual's personality or character (e.g. extrovert or introvert) and desirable behaviours refer to how an individual responds to stimuli (see Mullins, 2019, for further details of these classifications). A comparative mean among these three categories were illustrated in Figure 2 . Interestingly the result further confirmed that there was not a significant difference in the attributes expected by both graduate and parttime employers, apart from the skills category with $40 \%$ differences from total citations of jobs advertised. Personal attributes in behaviour, such as work ethics, attention to details, self-resilience and development were also found consistent among graduate and part-time employers. These attributes were regarded as important between the two type of jobs (see the score on ranking).

Meanwhile, attributes for traits, such as proactive, flexible/versatile, and passionate were almost equal to the average score of 14 citations among the 100 jobs reviewed from each job-type. However, the level of ranking for attributes on confident/outgoing personality and competitiveness were perceived more important for graduate positions than for part-time jobs. Further detail on the comparisons can be found in appendix 2 .

[Figure 2 to be placed here]

[Figure 3 to be placed here] 


\section{Conclusion}

The specified person criteria for graduate and part-time jobs demonstrated some notable similarities, particularly the importance of effective communication, providing excellent customer service and the ability to connect with colleagues and work in a team environment. This is important, since it suggests that students will be able to develop skills needed to secure graduate positions, courtesy of their part-time work activities. This research reconciles to the work of Muldoon (2009) who recognises the value of part-time work to graduate employability. In this way, part-time work should help provide students with a conduit into graduate jobs, by improving work-readiness.

The findings may have implications for students who need to look carefully at the part-time jobs they seek, in order to think more strategically on the implications for their career, rather than merely for maximum money or ease of fit to university timetable. It also will have implications for universities who need to encourage and support rather than deter part-time working, as previously recommended by Robotham (2012). Employers who depend upon student labour might consider offering more attractive propositions based on skill development, rather than monetary rewards. It will make those students who do not work, re-consider their situation. This may however, require students to stop thinking of themselves solely in students terms, but identify themselves as workers, for which part-time work is the first step in their respective careers. However, Daniels and Brooker (2014) find that students and workers have different identities in respect of work readiness, which could be problematic for students to embrace a different, more long-term perspective. Students may need to closely examine the specified job requirements of their desired graduate jobs and see what skills will be needed and map those out against their study, 
part-time work, placement and other experience. This will highlight any gaps that need to be filled in their make-up. If their existing skills do not reconcile to the desired graduate job, they should consider moving to part-time work or other work-related activities that will support and endorse their graduate credentials. Individuals will then need to highlight their transferable skills more effectively to employers. However, there is evidence that students do not really understand what value part-time work brings to their CV, merely having some vague hope that it adds value (Evans et al., 2014). This study identifies the value of that part-time work by linking person criteria to graduate positions. Here is where universities can help students identify gaps in their profiles and direct them accordingly, with Chen and $\mathrm{Hu}(2008)$ demanding that universities provide more guidance in supporting graduates into appropriate jobs.

There is clearly a role for universities in supporting and developing skills not developed by part-time work, particularly creative and innovative skills. Moreover, some criteria were somewhat tenuous, such as resilience, which is perhaps more implicitly demonstrated by students perhaps juggling part-time work, university, social life, or by knock-backs in university work and how they were overcome positively. Students will need to reflect on themselves to determine best examples of how this has been achieved. Nonetheless, the examples might be enhanced due to the part-time working activity, for example, good timemanagement could be demonstrated by explaining how managing to balance study, work and personal life was achieved.

This work has sought to examine graduate job skills against those specified in part-time jobs, in order to determine any relationship that might benefit university students in their pursuit of graduate positions. This study clearly highlights the importance of part-time jobs for 
students in supporting graduate applications. It is however, a small-scale piece of research, comprising a snapshot at a particular point of time, and therefore needing further analysis. It was anticipated that the job descriptions of part-time jobs could be assessed against graduate skills/behaviours. However, there was little specific connections to facilitate that study, with most related criteria being implied rather than explicitly expressed, for example keeping shelves stocked would support customer satisfaction for a shopping visit, but this was not clearly stated. Nonetheless, the job descriptions of part-time jobs are typically comprised of useful phrases that will support this endeavour, for example, "Ensuring high levels of customer satisfaction by being knowledgeable on all products offered, and teaming up with co-workers to provide excellent sales service". Graduates need to be able to recognise these useful phrases, using them to their advantage to articulate their work experience in graduate applications, in order to emphasise the skill developed in the parttime job. Again, university career services should be supporting this activity. This work could be further extended with qualitative analysis, especially through interviewing university students as to how part-time work is perceived to develop graduate skills, but also how it supports and drives their graduate career aspirations. The paper has also focused on the UK higher education and jobs market, and therefore any international context should be welcomed as a comparison, especially given the unique prevailing circumstances in the UK, of Brexit and Covid-19 adversely effecting education and industry. Moreover, a more longitudinal study to examine the effects of these factors, particularly if there is any structural change to both graduate and part-time jobs resulting from Brexit and Covid-19. 


\section{References}

Abdullah-Al-Mamun, M. (2012) The Soft Skills Education for the Vocational Graduate: Value as Work Readiness Skills, British Journal of Education, Society \& Behavioural Science, 2(4), 326-338.

Aggett, M. and Busby, G. (2011). Opting out of internship: Perceptions of hospitality, tourism and events management undergraduates at a British university, Journal of Hospitality Leisure Sport and Tourism Education, 10(1), 106-113.

Ayoubi, R. M., Alzarif, K. and Khalifa, B. (2017) The employability skills of business graduates in Syria: Do policymakers and employers speak the same language? Education + Training, 59(1), 61-75.

Baska, M. (2019) One in five graduates not workplace ready. [online]. People Management, 17 December. Available from;

https://www.peoplemanagement.co.uk/news/articles/graduates-not-workplace-ready

BBC (2019) Almost a third of graduates 'overeducated' for their job. [online]. BBC, 29 April. Available from; https://www.bbc.co.uk/news/business-48091971.

BBC (2015) Increase in students' working to fund studies. [online]. BBC, 10 August. Available from; https://www.bbc.co.uk/news/education-33843987) [accessed 26 March 2020].

Boden, R. and Nedeva, M. (2010) Employing discourse: universities and graduate 'employability', Journal of Education Policy, 25(1), 37-54 . 
Brooks, R. \& Youngson, P. L. (2016) Undergraduate work placements: an analysis of the effects on career progression, Studies in Higher Education, 41(9), 1563-1578.

Caballero, C. L. and Walker, A. (2010) Work readiness in graduate recruitment and selection: A review of current assessment methods, Journal of Teaching and Learning for Graduate Employability, 1(1), $13-25$.

Cavanagh, J., Burston, M., Amie Southcombe, C. and Bartram, T. (2015) Contributing to a graduate-centred understanding of work readiness: An exploratory study of Australian undergraduate students' perceptions of their employability, The International Journal of Management Education, 13, $278-288$.

Chavan, M. and Carter, L. (2018) Management students - expectations and perceptions on work readiness, International Journal of Educational Management, 32(5), 825-850.

Chen, C. and Hu, G. (2008) An empirical study of the influence of the concept of "jobhunting" on graduates' employment, Education China, 3(4): 569-584.

Crawford, I. \& Wang, Z (2016) The impact of placements on the academic performance of UK and international students in higher education, Studies in Higher Education, 41(4), 712733. 
Crockford, J., Hordósy, R., \& Simms, K. S. (2015) 'I really needed a job, like, for money and stuff': student finance, part-time work and the student experience at a northern red-brick university, Widening Participation and Lifelong Learning, 17(3), 89-109.

Curtis, S. (2007) Students' perceptions of the effects of term-time paid employment, Education + Training, 49(5), 380-390.

Curtis, S. \& Shani, N. (2002) The effect of taking paid employment during term-time on students' academic studies, Journal of Further and Higher Education, 26(2), 129-138.

Daniels, J. and Brooker, J. (2014) Student identity development in higher education: implications for graduate attributes and work-readiness, Educational Research, 56(1), 65-76.

Davies, C. (2020) Why is it so difficult for graduates to get a good job nowadays? [online]. Response Source, 8 January. Available from; https://pressreleases.responsesource.com/news/98973/why-is-it-so-difficult-for-graduatesto-get-a/

DfE (2019) Graduate labour market statistics 2018. [online]. Department for Employment, 25 April. Available from;

https://assets.publishing.service.gov.uk/government/uploads/system/uploads/attachment data/file/797308/GLMS 2018 publication main text.pdf. 
Ellis, M., Kisling, E. and Hackworth, R. G. (2014) Teaching Soft Skills Employers Need, Community College Journal of Research and Practice, 38(5), 433-453.

Evans, C., Maxfield, T. and Gbadamosi, G. (2015) Using part-time working to support graduate employment aspirations: Needs and perceptions of employers, Industry and Higher Education, 29(4), 305-314.

Evans, C. and Richardson, M. (2017) Enhancing graduate prospects by recording and reflecting on part-time work: A challenge to students and universities, Industry \& Higher Education, 31(5), 283-288.

Garner, B. R., Gove, M., Ayala, C. and Mady, A. (2019) Exploring the gap between employers' needs and undergraduate business curricula: A survey of alumni regarding core business curricula, Industry and Higher Education, 33(6) 439-447.

Gonzalez-Roma, V., Gamboa, J. P. and Peior, J. M. (2018) Industry and Higher Education, 45(2) 132-149.

Gordon, J. (2020) Class of 2020 faces one of the bleakest job markets in history as students graduate in virtual ceremonies with coronavirus pandemic preventing the usual pomp and circumstance.[online]. Dailymail, 4 May. Available from;

https://www.dailymail.co.uk/news/article-8282937/Class-2020-face-bleakest-job-marketshistory-students-graduate-virtual-ceremonies.html. Hedvicakova, M. (2018) Unemployment and effects of the first work experience of university graduates on their idea of a job, Applied Economics, 50(31), 3357-3363. 
Herbert, I. P., Rothwell, A. T., Glover, J. L. and Lambert, S. A. (2020) Graduate employability, employment prospects and work readiness in the changing field of professional work, The International Journal of Management Education, 18, 100378.

HESA (2020) Higher Education Student Statistics: UK, 2018/19 - Student numbers and characteristics Statistical Bulletin SB255 on 29 January 2020. [online]. Available from; https://www.hesa.ac.uk/news/16-01-2020/sb255-higher-education-studentstatistics/numbers

Highfliers (2019) The Graduate Market in 2019, London, Highfliers Research Ltd.

Hwang, Y. (2017) What Is the Cause of Graduates' Unemployment? Focus on Individual Concerns and Perspectives, Journal of Educational Issues, 3(2), 1 - 10.

ISE (2019) Employers cut entry-level jobs by $23 \%$ due to corona crisis. [online]. Institute of Student Employers, 18 May. Available from;. https://ise.org.uk/page/PressReleases.

Jackson, D. (2013) Factors influencing job attainment in recent Bachelor graduates: evidence from Australia, Higher Education, 68. 135 - 153.

Jackson, D. (2015) Employability skill development in work-integrated learning: Barriers and best practice, Studies in Higher Education, 40:2, 350-367.

Jackson, D., Rowbottom, D., Ferns, S. and McLaren, D. (2016): Employer understanding of Work-Integrated Learning and the challenges of engaging in work placement opportunities, Studies in Continuing Education, DOI: 10.1080/0158037X.2016.1228624. 
Jasiński, M. and Bożykowski, M. (2017) Who gets a job after graduation? Factors affecting the early career employment chances of higher education graduates in Poland, Edukacja, 4(143), 17-30.

Jollands, M., Jolly, L. and \& Molyneaux, T. (2012) Project-based learning as a contributing factor to graduates' work readiness, European Journal of Engineering Education, 37(2), 143154.

Jones, E. (2017) The biggest challenges facing university graduates.[online]. Recruiting Times, 10 October. Available from; https://recruitingtimes.org/business-moversshakers/21246/biggest-challenges-facing-university-graduates/

Kapareliotis, I., Voutsina, K. and Athanasios Patsiotis, A. (2019) Higher Education, Skills and Work-Based Learning, 9(4), 538-549.

Konig, L. S. and Ribaric, H. M. (2019) Is there a mismatch between employers' and university teachers' perceptions on graduate employability in Croatia? Journal of Contemporary Management Issues, 24(1), 87-102.

Little, B. (2005) Policies towards work-focused higher education - are they meeting employers' needs? Tertiary Education and Management, 11, 131-146.

MacMillan, L., Tyler, C. and Vignoles, A. (2014) Who Gets the Top Jobs? The Role of Family Background and Networks in Recent Graduates' Access to High-status Professions, Journal of Social Policy, 44(3), 487-515. 
McArthur, E., Kuback, K.,, Pang, B. and Alcaraz, C. (2017) The Employers' View of “WorkReady" Graduates: A Study of Advertisements for Marketing Jobs in Australia, Journal of Marketing Education, 39(2) 82 - 93.

McKeown, T. and Lindorff, M. (2011) The graduate job search process - a lesson in persistence rather than good career management? Education \& Training, 53(4), 310-320.

McVicar, D. and McKee, B. (2002), "Part-time work during post-compulsory education and examination performance: help or hindrance?", Scottish Journal of Political Economy, Vol. 49 No. 4,393-406.

Mavromaras, K., McGuinness, S., O’ Leary, N., Sloane, P. and Wei, Z. (2013) Job Mismatches and Labour Market Outcomes: Panel Evidence on University Graduates, Economic Record, 89(286), 382-395.

Neil, N., Mulholland, G., Ross, V. and Leckey, J. (2004) The Influence of Part-time Work on Student Placement, Journal of Further and Higher Education, 28(2), 123 - 137.

O’Brien, K., Hartley, P., Dawson, D., Quick, J. and Moore, A. (2013) International Paramedic Practice, 3(4), $98-104$.

Mari, T. S., Srirangam, S., Gunasagaran, S., Kuppusamy, S. .and Ang, F. L. (2019) Architecture graduate work readiness: The gap between learning and employability, 3rd International Conference on Architecture and Civil Engineering (ICACE 2019), IOP Conf. Series: Materials Science and Engineering 636, (2019) 012010, IOP Publishing doi:10.1088/1757899X/636/1/012010. 
Mok, K. O. and Jiang, J. (2018) Massification of higher education and challenges for graduate employment and social mobility: East Asian experiences and sociological reflections, International Journal of Educational Development, 63, $44-51$.

Muldoon, R. (2009). Recognizing the enhancement of graduate attributes and employability through part-time work while at university, Active Learning in Higher Education, 10(3), 23725.

Mullins, L. (2019) Organisational behaviour in the workplace, $12^{\text {th }}$ Ed. Harlow, Pearson.

NUS (2019) How to balance work and study. NUS, 26 November. [online]. Available from: http://nus.org.uk/en/advice/careers/how-to-balance-work-and-study

NUS (2020) Coronovirus and students survey. NUS April. NUS Insight. Available from: https://www.nus.org.uk/en/news/press-releases/nus-sets-out-safety-net-needs-forstudents/

Owen, E. (2001) Owen (2001) What Key Skills do Employers Need?, Journal of Geography in Higher Education, 25:1, 121-126.

Paisley, C. \& Paisley, N. J. (2010) Developing skills via work placements in accounting: students and employer views, Accounting Forum, 34, 89-108.

Prikshat, V., Montague, A., Connell, J. and Burgess, J. (2019) Australian graduates' work readiness - deficiencies, causes and potential solutions, Higher Education, Skills and WorkBased Learning, DOI 10.1108/HESWBL-02-2019-0025. 
Rhew, N. D., Black, J. A. and Keels, J. J. (2019) Are we teaching what employers want? Identifying and remedying gaps between employer needs, accreditor prescriptions, and undergraduate curricular priorities, Industry and Higher Education, 33(6) 362-369.

Richardson, M., Evans, C. and Gbadamosi, G. (2009) Funding Full-Time Study through PartTime Work, Journal of Education and Work , 22(4), 319 - 334.

Ritter, B. A., Erika E. Small, E. E., Mortimer, J. W. and Doll, J. L. (2018) Designing Management Curriculum for Workplace Readiness: Developing Students' Soft Skills, Journal of Management Education, 42(1) 80 - 103.

Robotham, D. (2012) Student part-time employment: characteristics and consequences, Education +

Training, 54(1), 65-75

Saunders, V. and Zuzel, K. (2010) Evaluating Employability Skills: Employer and Student Perceptions, Bioscience Education, 15(2),

Sales, D. and Tapsfield, J. (2020) City's biggest firms will only bring back up to $50 \%$ of staff to the office so they don't break social distancing rules despite calls from Boris Johnson for workers to return. [online]. Mailonline, 13 July 2020. Available from:

https://www.dailymail.co.uk/news/article-8516723/Big-firms-no-rush-return-headquartersbiggest-employers-planning-40-back.html,.

Sam, V. (2019) Impacts of educational mismatches on job satisfaction. The case of university graduates in Cambodia, International Journal of Manpower, DOI 10.1108/IJM-07-20180229. 
Steed, S. (2018) Too many graduates are mismatched to their jobs. What's going wrong?

[online]. The Guardian, 25 January. Available from; https://www.theguardian.com/highereducation-network/2018/jan/25/too-many-graduates-are-mismatched-to-their-jobs-whatsgoing-wrong.

Targetjobs (2020) What is a graduate job? Targetjobs. Available from:

https://targetjobs.co.uk/careers-advice/career-planning/473800-what-is-a-graduate-job

Teng, W. and Ma, C. (2019) Graduate readiness for the employment market of the $4^{\text {th }}$ industrial revolution. The development of soft employability skills, Education + Training, 61(5), 590-604.

Tight, M. (2017) Mass higher education and massification, Higher Education Policy, 32(1), 93 $-108$.

Vendolska, I. and Eliska, K. (2016) Flexible Graduate is Successful Graduate. Key Factors of Successful Job Interview, Results of a Comparative Analysis, Journal of Competitiveness, $8(2), 87-102$.

von Sternberg, L. (2019) Will Brexit affect the graduate job market? [online]. Prorecruitment, April. Available from; https://www.pro-recruitment.co.uk/blog/2019/04/willbrexit-affect-the-graduate-job-market.

Wellman, N. (2010) The employability attributes required of new marketing graduates, Marketing Intelligence \& Planning, 28(7), $908-930$.

Zakariya, Z. (2017) Job Mismatch and On-the-job Search Behavior Among University Graduates in Malaysia, Asian Economic Journal, 31(4), 355-379. 
[Appendix 1 to be placed here]

[Appendix 2 to be placed here] 
The Importance of Part-Time Work to UK University Students

\section{Tables and Figures}

Table 1: Graduate Criteria identified in Graduate Jobs

\begin{tabular}{|l|c|c|}
\hline Skills, Traits, Behaviours specified in Graduate Jobs & $\begin{array}{c}\text { No. of Times } \\
\text { Cited in } \\
\text { Graduate Jobs }\end{array}$ & Ranking \\
\hline Analytical skills/Think Logically/Structured approach to decisions & 25 & 6 \\
\hline Problem solver & 20 & $=12$ \\
\hline $\begin{array}{l}\text { Excellent Communication skills (verbal, presentation, } \\
\text { written)/ articulate/eloquent) }\end{array}$ & 69 & 1 \\
\hline Strong work ethic/Hardworking & 18 & $=14$ \\
\hline Attention to detail & 27 & 3 \\
\hline Excellent customer/Client service & 14 & 21 \\
\hline IT/Digital Skills/MS programs & 26 & $=4$ \\
\hline Organisational skills/Planning skills/Well organised & 28 & 2 \\
\hline $\begin{array}{l}\text { Curious/Inquisitive/Open-minded/ } \\
\text { Creative/Innovative/Entrepreneurial/ New ways of } \\
\text { thinking/Think Outside the box/New ideas }\end{array}$ & 23 & $=8$ \\
\hline Resilience/Persistence/Tenacious & & \\
\hline Proactive/Can-do attitude/Self-starter/Work on own initiative & 15 & 20 \\
\hline Leadership skills/qualities & 21 & 11 \\
\hline Partner with other people/Team player & 9 & 23 \\
\hline Flexible/Adaptable/Versatile/Embrace change & 24 & 7 \\
\hline Motivated/Self-motivated & 16 & 19 \\
\hline Build/Nurture relationships (mainly specified with clients) & 18 & $=14$ \\
\hline Time management skills/Tight deadlines/Prioritise/ Work under & 17 & 18 \\
\hline pressure & 20 & $=12$ \\
\hline Commitment to self-development/Growth/Willingness to learn & 23 & $=8$ \\
\hline Commitment to values (e.g. Diversity, integrity) & 4 & 26 \\
\hline Commercial awareness/Business Acumen/Current affairs & 18 & $=14$ \\
\hline Confident/Outgoing personality & 18 & $=14$ \\
\hline Task Driven/Target driven & 10 & 22 \\
\hline Reliable/Dependable & 1 & 27 \\
\hline Project management skills & 6 & 25 \\
\hline Aptitude for numbers/Numerically confident & 7 & 24 \\
\hline Positive energy/Energetic/Enthusiastic/Passionate & 23 & $=8$ \\
\hline Ambitious/Determined to succeed/Competitive & 26 & $=4$ \\
\hline & & \\
\hline & & \\
\hline & & \\
\hline
\end{tabular}


Table 2: Graduate Criteria identified in Part-Time Jobs

\begin{tabular}{|c|c|c|}
\hline Skills, Traits, Behaviours specified in Graduate Jobs & $\begin{array}{l}\text { No. of Times } \\
\text { Cited in Part- } \\
\text { Time Jobs }\end{array}$ & Ranking \\
\hline Analytical skills/Think Logically/Structured approach to decisions & 1 & $=22$ \\
\hline Problem solver & 1 & $=22$ \\
\hline $\begin{array}{l}\text { Excellent Communication skills (verbal, presentation, } \\
\text { written)/ articulate/eloquent) }\end{array}$ & 47 & 2 \\
\hline Strong work ethic/Hardworking & 11 & 14 \\
\hline Attention to detail & 18 & 9 \\
\hline Excellent customer/Client service & 41 & 3 \\
\hline IT/Digital Skills/MS programs & 16 & 10 \\
\hline Organisational skills/Planning skills/Well organised & 19 & 8 \\
\hline $\begin{array}{l}\text { Curious/Inquisitive/Open-minded/ } \\
\text { Creative/Innovative/Entrepreneurial/ New ways of } \\
\text { thinking/Think Outside the box/New ideas }\end{array}$ & 0 & $=26$ \\
\hline Resilience/Persistence/Tenacious & 3 & $=18$ \\
\hline Proactive/Can-do attitude/Self-starter/Work on own initiative & 25 & 5 \\
\hline Leadership skills/qualities & 3 & $=18$ \\
\hline Partner with other people/Team player & 52 & 1 \\
\hline Flexible/Adaptable/Versatile/Embrace change & 23 & 6 \\
\hline Motivated/Self-motivated & 8 & $=15$ \\
\hline Build/Nurture relationships (mainly specified with clients) & 13 & $=11$ \\
\hline $\begin{array}{l}\text { Time management skills/Tight deadlines/Prioritise/ Work under } \\
\text { pressure }\end{array}$ & 21 & 7 \\
\hline Commitment to self-development/Growth/Willingness to learn & 12 & 13 \\
\hline Commitment to values (e.g. Diversity, integrity) & 3 & $=18$ \\
\hline Commercial awareness/Business Acumen/Current affairs & 1 & $=22$ \\
\hline Confident/Outgoing personality & 4 & 17 \\
\hline Task Driven/Target driven & 13 & $=11$ \\
\hline Reliable/Dependable & 8 & $=15$ \\
\hline Project management skills & 1 & $=22$ \\
\hline Aptitude for numbers/Numerically confident & 2 & 21 \\
\hline Positive energy/Energetic/Enthusiastic/Passionate & 27 & 4 \\
\hline Ambitious/Determined to succeed/Competitive & 0 & $=26$ \\
\hline
\end{tabular}


Figure 1: Positive relationship of graduate and part-time job attribute

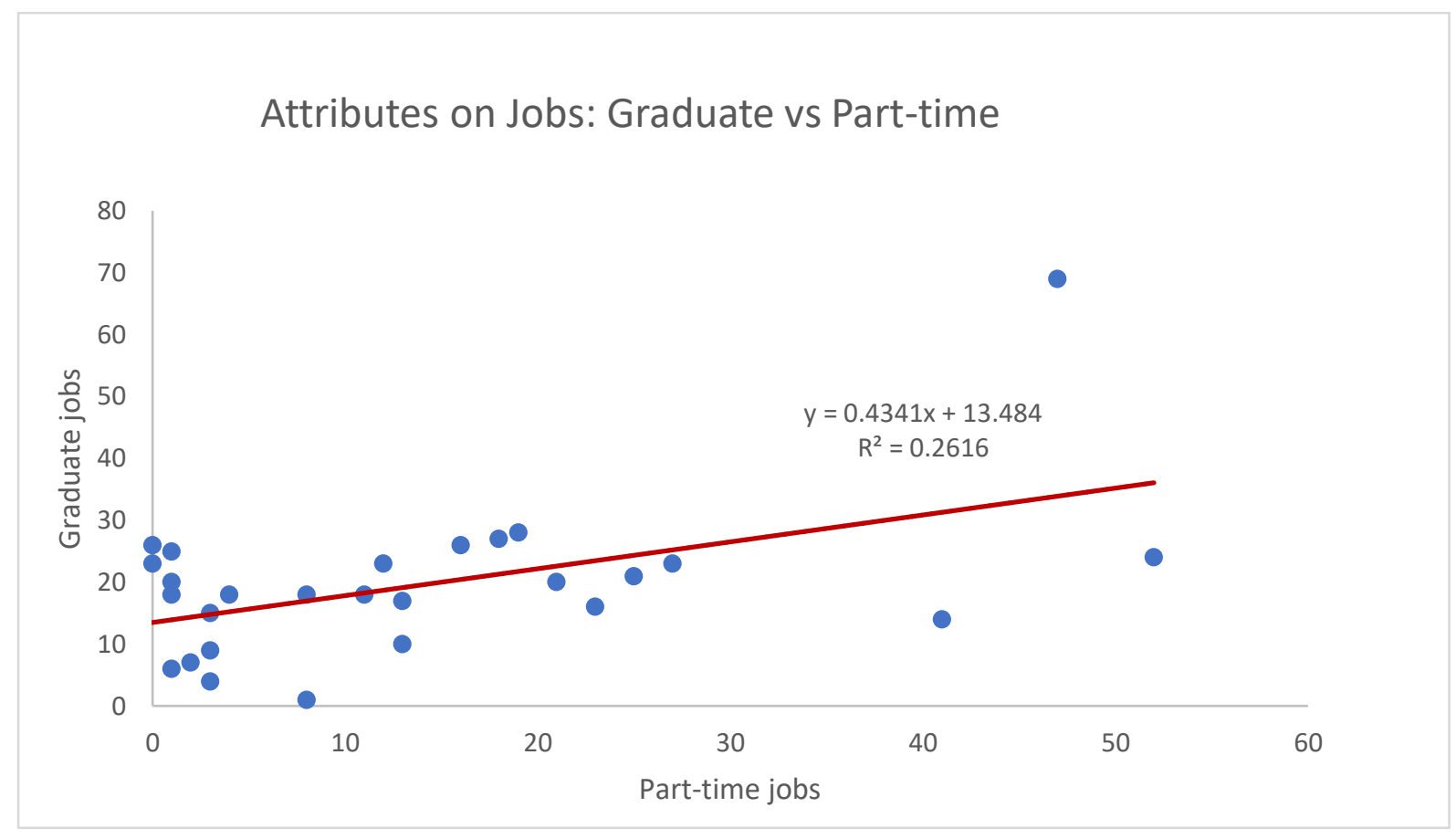

Figure 2: Mean of citations based on skills, traits and behaviours between two jobs: Graduate and Part-time

Comparing Attributes with Graduate and Part-time Jobs

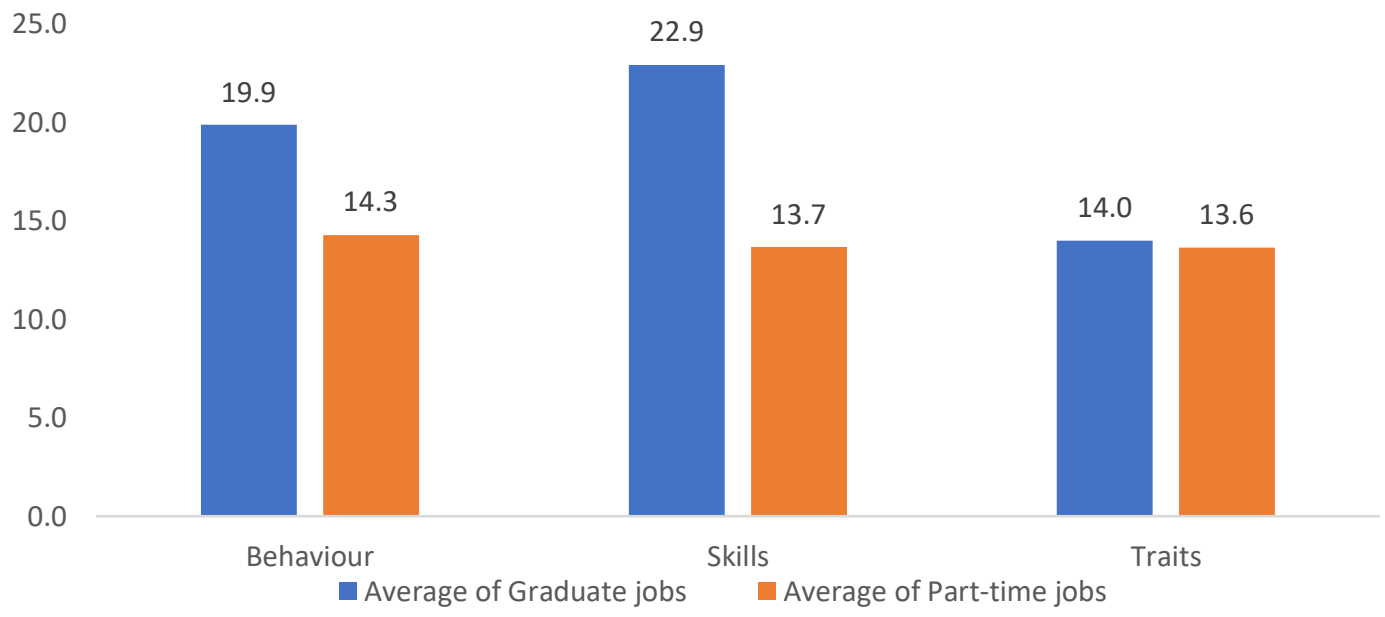


Figure 3: Expected skills recognised by employers

\section{Expected Skills in Graduate and Part-time Jobs}

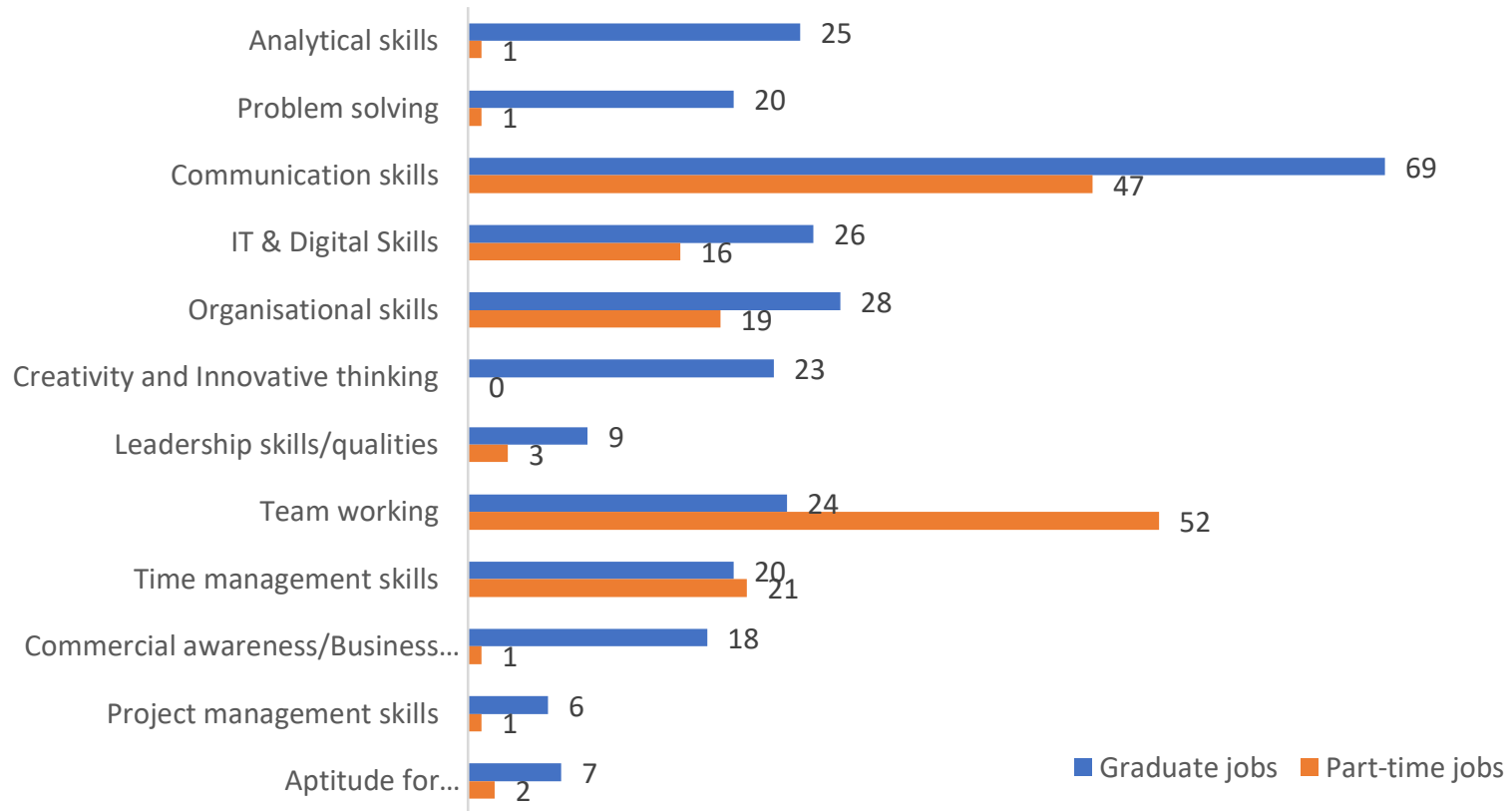


Appendix 1: Output of regression analysis between graduate and part-time job's attributes

\begin{tabular}{lr}
\hline \multicolumn{2}{c}{ Regression Statistics } \\
\hline Multiple R & 0.5115 \\
R Square & 0.2616 \\
Adjusted R Square & 0.2321 \\
Standard Error & 10.8047 \\
Observations & 27 \\
\hline
\end{tabular}

ANOVA

\begin{tabular}{lrrrrrr}
\hline & & & & & \multicolumn{2}{c}{ Significance } \\
& $d f$ & & SS & MS & $F$ & $F$ \\
\hline Regression & & 1 & 1034.218011 & 1034.218 & 8.8591 & 0.0064 \\
Residual & & 25 & 2918.522729 & 116.7409 & & \\
Total & & 26 & 3952.740741 & & & \\
\hline
\end{tabular}

\begin{tabular}{|c|c|c|c|c|c|c|c|c|}
\hline & & Standard & & $P-$ & & Upper & Lower & Upper \\
\hline & Coefficients & Error & t Stat & value & Lower 95\% & $95 \%$ & $95.0 \%$ & $95.0 \%$ \\
\hline Intercept & 13.4844 & 2.8954 & 4.6571 & 0.0001 & 7.5212 & 19.4476 & 7.5212 & 19.4476 \\
\hline Part-time jobs & 0.4341 & 0.1458 & 2.9764 & 0.0064 & 0.1337 & 0.7345 & 0.1337 & 0.7345 \\
\hline
\end{tabular}


Appendix 2: Comparison on jobs attributes between graduate and part-time jobs

\section{Expected Skills, Traits \& Behaviours in Jobs: Graduate Vs Part-time}

Ambitious/Determined to succeed/Competitive Positive energy/Energetic/Enthusiastic/Passionate

Aptitude for numbers/Numerically confident

Project management skills

Reliable/Dependable

Task Driven/Target driven Confident/Outgoing personality

Commercial awareness/Business Acumen/Current affairs

Commitment to values (e.g. Diversity, integrity)

Commitment to self-development/Growth/Willingness to learn

Time management skills

Build/Nurture relationships (mainly specified with clients)

Motivated/Self-motivated

Flexible/Adaptable/Versatile/Embrace change

Team working

Leadership skills/qualities

Proactive and self-belief

Resilience/Persistence/Tenacious

Creativity and Innovative thinking

Organisational skills

IT \& Digital Skills

Customer/Client service

Attention to detail

Work ethics

Communication skills

Problem solving

Analytical skills

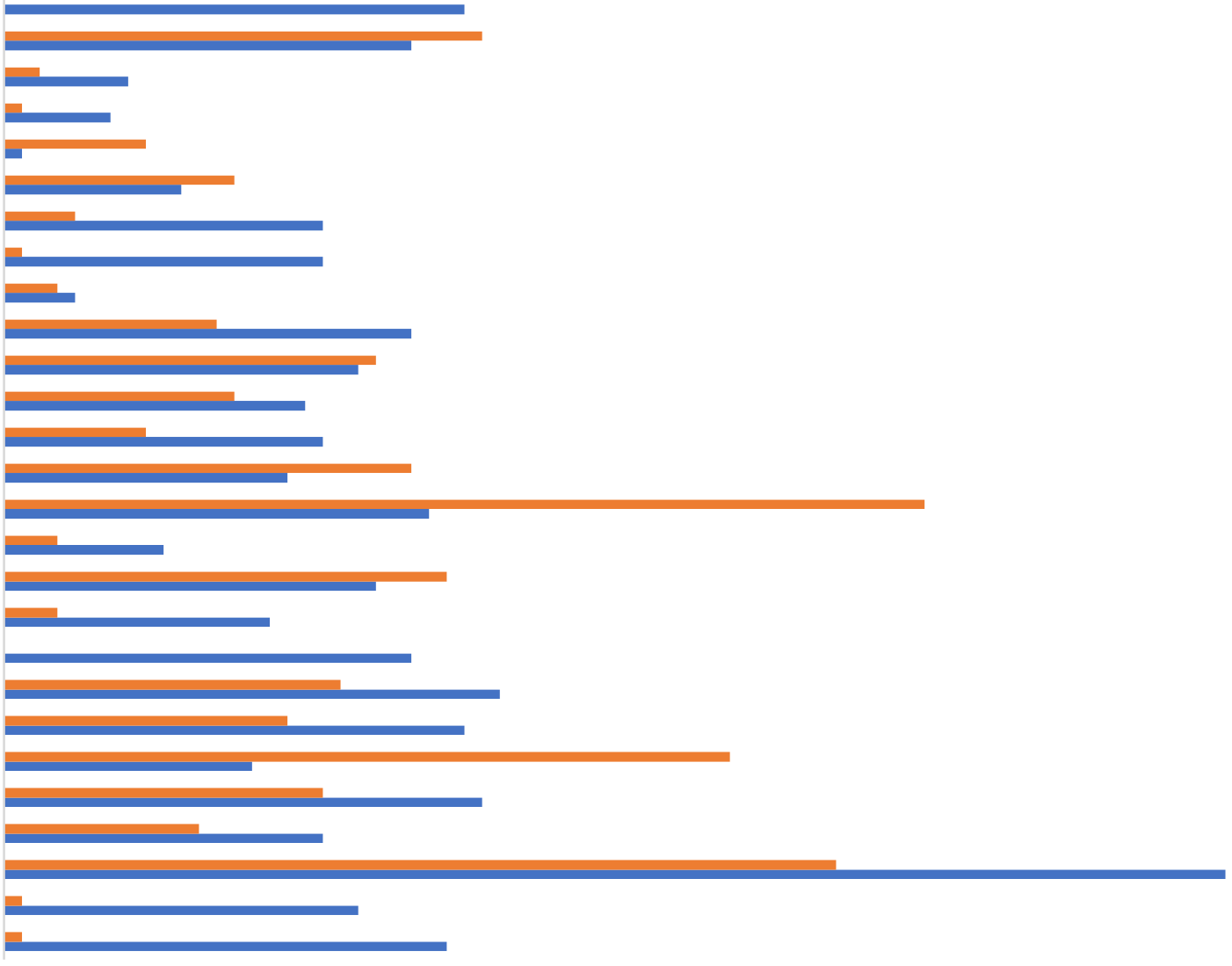

Part-time jobs

n Graduate jobs

Frequency of citations in job 
